International Journal of Mechanical Engineering and Technology (IJMET)

Volume 12, Issue 2, February 2021, pp. 41-50. Article ID: IJMET_12_02_005

Available online at https://iaeme.com/Home/issue/IJMET?Volume=12\&Issue=2

ISSN Print: 0976-6340 and ISSN Online: 0976-6359

DOI: https://doi.org/10.34218/IJMET.12.2.2021.005

C IAEME Publication

Scopus Indexed

\title{
COMPARATIVE STUDIES ON CONTROL OF EMISSIONS OF TWO STROKE AND FOUR STROKE SPARK IGNITION ENGINES
}

\author{
N. Venkateshwararao \\ Mechanical Engineering Department, Chaitanya Bharathi Institute of Technology, \\ Gandipet, Hyderabad, India \\ M. V. S. Murali Krishna* \\ Mechanical Engineering Department, Chaitanya Bharathi Institute of Technology, \\ Gandipet, Hyderabad, India \\ Ch. Indira Priyadarshini \\ Mechanical Engineering Department, Chaitanya Bharathi Institute of Technology, \\ Gandipet, Hyderabad, India \\ Y. Nagine \\ Mechanical Engineering Department, Chaitanya Bharathi Institute of Technology, \\ Gandipet, Hyderabad, India \\ *Corresponding Author
}

\begin{abstract}
Alcohols are proved to be efficient fuels for petrol engine, as their octane rating are very high and that too, there are renewable in nature. The exhaust emissions of petrol engine cause human hazards, once they are inhaled in and also cause environmental effects like Greenhouse effect and acid rains. Hence control of these pollutants is an immediate step and an urgent task. Investigations were carried out to determine and control the exhaust emissions of carbon monoxide (CO) and un-burnt hydro carbons (UBHC) emissions of two stroke and four stroke of single cylinder, spark ignition (SI)engine having copper coated engine [CCE, copper-(thickness, $300 \mu$ ) coated on piston crown and inner side of cylinder head] provided with catalytic converter with sponge iron as catalyst with methanol blended gasoline (80\% gasoline and $20 \%$ methanol by volume) and compared with conventional engine $(C E)$ with neat gasoline operation. The engine was provided with catalytic converter with sponge iron as catalyst. There was provision for injection of air into the catalytic converter. CCE showed reduction of pollutants, when compared with CE with both test fuels. 4-Stroke engine decreased exhaust emissions effectively in comparison with 2-stroke engine with
\end{abstract}


both versions of the engine at same compression ratio. Catalytic converter with air injection significantly reduced pollutants with different test fuels on both configurations of the engine.

Keywords: Alternative fuels, Methanol, CE, CCE, Fuel Performance, Exhaust emissions and Catalytic converter.

Cite this Article: N. Venkateshwararao, M. V. S. Murali Krishna, Ch. Indira Priyadarshini and Y. Nagine, Comparative Studies on Control of Emissions of Two Stroke and Four Stroke Spark Ignition Engines, International Journal of Mechanical Engineering and Technology (IJMET), 12(2), 2021, pp.41-50.

https://iaeme.com/Home/issue/IJMET?Volume=12\&Issue $=2$

\section{INTRODUCTION}

In the context of fast depletion of fossil fuels, the search for alternative fuels has become pertinent. Alcohols are probable candidates as alternative fuels for spark ignition (SI) engines, as their properties are compatible close to gasoline fuels. If alcohols are blended in small quantities with gasoline fuels, no engine modification is necessary. These alcohols can be prepared from municipal waste.[1].

The major exhaust emissions from SI engine are carbon monoxide (CO) and un-burnt hydrocarbons (UBHC), formed due to incomplete combustion of fuel. Inhaling of these pollutants cause [1-6] severe headache, vomiting sensation, loss of hemoglobin in the blood, respiratory problems etc,. Such pollutants also cause detrimental effects [6] on animal and plant life, besides environmental disorders. If the engine is run with alcohol, aldehydes are also to be checked. These aldehydes are carcinogenic in nature. The amount of exhaust emissions from the engine depends [2] on driving engine condition, driving methodology, road layout, traffic density, etc,. Hence control of these emissions is immediate and an urgent task. There are many methods to improve the performance of the engine out of which engine modification [7-11] with copper coating on piston crown and inner side of cylinder head improves engine performance as copper is a good conductor of heat and combustion and pre-flame reactions were improved with copper coating. Out of many methods available to control pollutants from SI engine, catalytic converter is effective [12-15] in reduction of pollutants in SI engine. The reduction of $\mathrm{CO}$ and $\mathrm{UBHC}$ depends on mass of the catalyst, void ratio, temperature of the catalyst, air flow rate, BMEP, speed and compression ratio of the engine, Engine performance improved [16-21] with change in fuel composition also. It was further improved [22-26] with simultaneous change of fuel composition and engine modification. Alcohols are blended with gasoline and used in copper coated engine so as to improve the performance of the engine. However, no systematic investigations were reported with the use of methanol blended gasoline in 2 stroke and 4 stroke copper coated engine with varied engine parameters.

The present paper reported the control of exhaust emissions of 2-stroke and 4-stroke CCE, with methanol blended gasoline at the same compression ratio. The exhaust emissions of $\mathrm{CO}$, UBHC and aldehydes were controlled by catalytic converter with sponge iron as catalyst.

\section{MATERIALS AND METHODS}

Figure.1consisted 4-stroke CCE with methanol blended gasoline, used in the experiment. A four- stroke, single-cylinder, water-cooled, SI engine (brake power $2.2 \mathrm{~kW}$, at the speed 3000 $\mathrm{rpm}$ ) was coupled to an eddy current dynamometer for measuring its brake power. The bore of the engine was $70 \mathrm{~mm}$ while the stroke was $66 \mathrm{~mm}$. Compression ratio of engine was varied (3-9) with change of clearance volume by adjustment of cylinder head, threaded to cylinder of the engine. However, compression ratio was maintained as 7.5:1, as the compression ratio of 2 
stroke engine was also 7.5:1, as there should not be any effect of compression ratio on exhaust emissions of the engine. Engine speeds were varied from 2000 to $3000 \mathrm{rpm}$. Exhaust gas temperature was measured with iron- constantan thermocouples. Fuel consumption of engine was measured with burette method, while air consumption was measured with an air-box method.

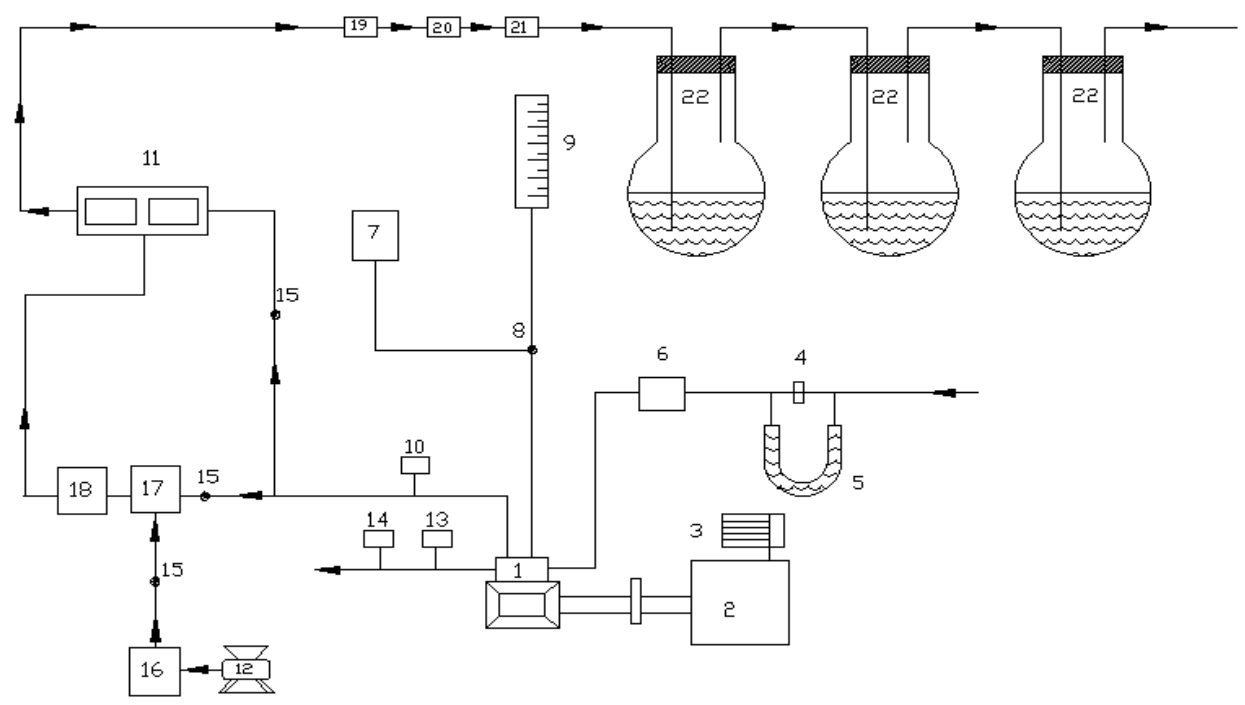

1. Engine, 2.Eddy current dynamometer, 3. Loading arrangement, 4. Orifice meter, 5. U-tube water monometer, 6. Air box, 7. Fuel tank, 8. Three-way valve, 9. Burette,10. Exhaust gas temperature indicator, 11 $\mathrm{CO}$ analyzer, 12. Air compressor, 13. Outlet jacket water temperature indicator, 14. Outlet jacket water flow meter,15. Directional valve, 16. Rotometer, 17. Air chamber and 18. Catalyst chamber 19. Filter, 20. Rotometer, 21. Heater, 22. Round bottom flasks containing DNPH solution

Figure 1 Experimental set up (4-Stroke Engine

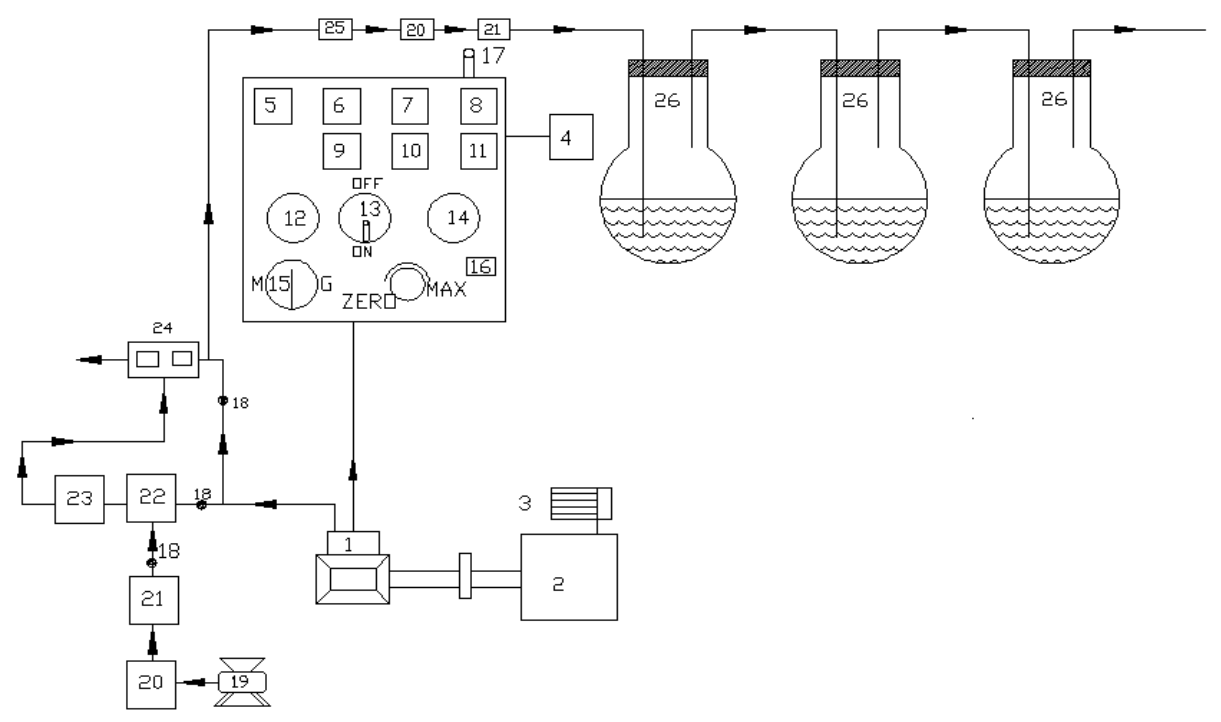

1. Engine, 2.Electrical swinging field dynamometer, 3. Loading arrangement, 4.Fuel tank, 5.Torque indicator/controller sensor, 6. Fuel rate indicator sensor, 7. Hot wire gas flow indicator, 8. Multi channel temperature indicator, 9. Speed indicator, 10. Air flow indicator, 11. Exhaust gas temperature indicator, 12.

Mains ON, 13. Engine ON/OFF switch, 14. Mains OFF, 15. Motor/Generator option switch, 16. Heater controller, 17. Speed indicator, 18. Directional valve, 19. Air compressor, 20. Rotometer, 21. Heater, 22. Air chamber, 23. Catalytic chamber, 24. CO/HC analyzer, 25. Filter,

26. Round bottom flasks containing DNPH solution,

Figure 2 Schematic diagram of the Experimental Set-up (2-Stroke) 
The experimental setup contained 2-stroke CCE with methanol blended gasoline is shown in Figure 2. A two- stroke, single-cylinder, air -cooled, SI engine (brake power $2.2 \mathrm{~kW}$ at the speed of $3000 \mathrm{rpm}$ ) was coupled to a eddy current dynamometer for measuring its brake power. The bore and stroke of engine cylinder was $57 \mathrm{~mm}$ each. Compression ratio of engine was 7.5:1. Exhaust gas temperature, speed, torque, fuel consumption and air flow rate of the engine were measured with electronic sensors. Compression ratio and speed of 4-stroke engine was made equal (3000 rpm and 7.5:1) to that of 2-stroke engine in order to maintain same conditions for comparison purpose.

Fig.3 shows schematic diagram of catalytic converter.

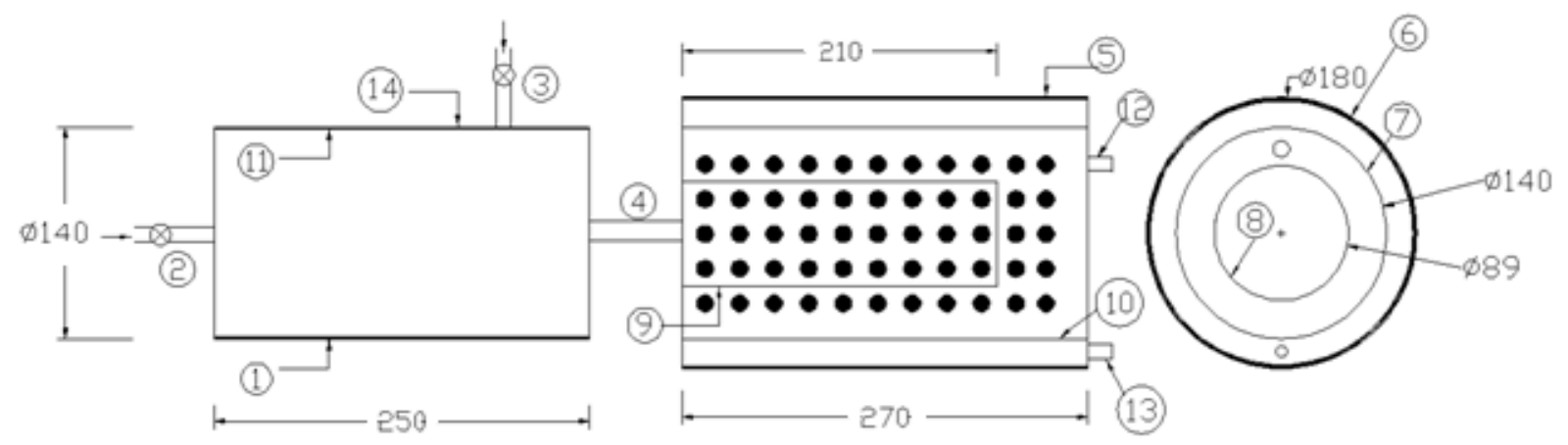

1.Air chamber, 2. Inlet for air chamber from the engine, 3. Inlet for air chamber from the compressor, 4. Outlet for air chamber, 5. Catalytic chamber, 6. Outer cylinder, 7. Intermediate-cylinder, 8. Inner-cylinder, 9.Inner sheet, 10.Intermediate sheet, 11. Outer sheet, 12. Outlet for exhaust gases, 13. Provision to deposit the catalyst, and, 14. Insulation.

Figure 3 Details of Catalytic converter

In catalytic coated engine, piston crown and inner surface of cylinder head were coated with copper by flame spray gun. The surface of the components to be coated were cleaned and subjected to sand blasting. A bond coating of nickel- cobalt- chromium of thickness 100 microns was sprayed over which copper $(89.5 \%)$, aluminium $(9.5 \%)$ and iron (1\%) alloy of thickness 300 microns was coated with METCO (Trade name of the company) flame spray gun. The coating has very high bond strength and does not wear off even after $50 \mathrm{~h}$ of operation [7].

$\mathrm{CO}$ and UBHC emissions in engine exhaust were measured with Netel Chromatograph analyzer. DNPH method [27-29] was employed for measuring aldehydes in the experimentation. The exhaust of the engine was bubbled through 2,4 dinitrophenyl hydrazine (2,4 DNPH) solution. The hydrazones formed were extracted into chloroform and were analyzed by employing high performance liquid chromatography (HPLC) to find the percentage concentration of formaldehyde and acetaldehyde in the exhaust of the engine.

A catalytic converter [12] (Figure .3) was fitted to exhaust pipe of engine. Provision was also made to inject a definite quantity of air into catalytic converter. Air quantity drawn from compressor and injected into converter was kept constant so that backpressure does not increase. Experiments were carried out on $\mathrm{CE}$ and $\mathrm{CCE}$ with different test fuels under different operating conditions of catalytic converter like set-A, without catalytic converter and without air injection; set-B, with catalytic converter and without air injection; and set-C, with catalytic converter and with air injection. The accuracy of the instrumentation used in the experimentation is $0.1 \%$.

\section{RESULTS AND DISCUSSION}

\subsection{Exhaust Emissions}

Figure. 4 shows variation of $\mathrm{CO}$ emissions with brake mean effective pressure (BMEP) of the engine for 2 stroke SI engine, at a compression ratio of 7.5:1 and speed $3000 \mathrm{rpm}$. Curves from 
Fig.4.indicate that methanol blended gasoline operation decreased $\mathrm{CO}$ emissions at all loads when compared to neat gasoline operation on CCE and CE, as fuel-cracking reactions were eliminated with methanol. The combustion of alcohol produced more water vapor than free carbon atoms as methanol has lower $\mathrm{C} / \mathrm{H}$ ratio of 0.33 against 0.44 of gasoline. Methanol has oxygen in its structure and hence its blends have lower stoichiometric air requirements compared to gasoline. Therefore more oxygen that was available for combustion with the blends of methanol and gasoline, lead to reduction of $\mathrm{CO}$ emissions. Methanol dissociated in the combustion chamber of the engine forming hydrogen, which helped the fuel-air mixture to burn quickly and thus increases combustion velocity, which brought about complete combustion of carbon present in the fuel to $\mathrm{CO}_{2}$ and also $\mathrm{CO}$ to $\mathrm{CO}_{2}$ thus made leaner mixture more combustible, causing reduction of $\mathrm{CO}$ emissions. $\mathrm{CCE}$ reduced $\mathrm{CO}$ emissions in comparison with CE. Copper or its alloys acted as catalyst in combustion chamber, whereby facilitated effective combustion of fuel leading to formation of $\mathrm{CO}_{2}$ instead of $\mathrm{CO}$. Similar trends were observed with Reference-10 with pure gasoline operation on CCE.

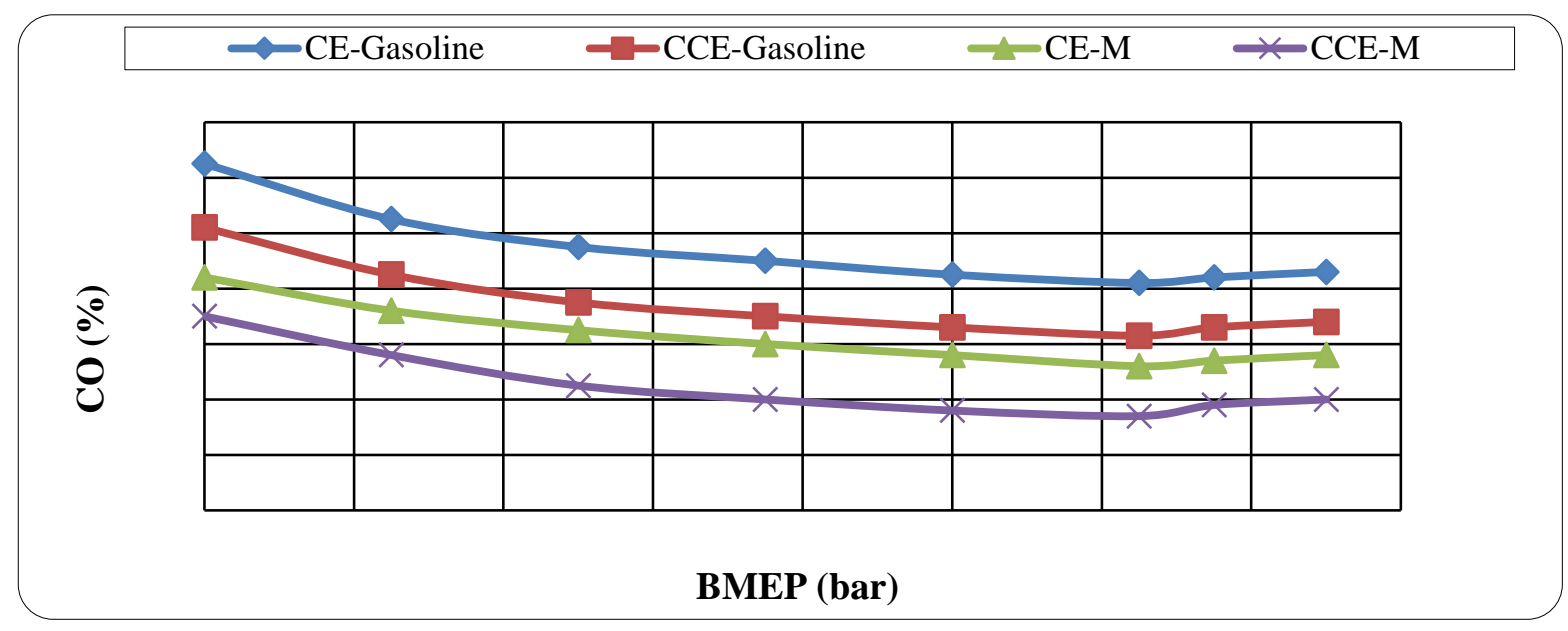

Figure 4 Variation of $\mathrm{CO}$ emissions with BMEP of the 2-Stroke

Figure. 5 presents bar charts showing the variation of $\mathrm{CO}$ emissions at full load for 2 stroke and 4 stroke SI engine with different test fuels and with different configurations of the engine. From Fig.5, it is noticed that CO emissions were observed to be lower with 4 stroke engine in comparison with 2 stroke engine at peak load operation on both versions of the engine. This was due to incomplete combustion of fuel and lower thermal efficiency of 2 stroke engine. Complete fuel will not participate in combustion reactions causing increase of $\mathrm{CO}$ emissions with 2 stroke engine.

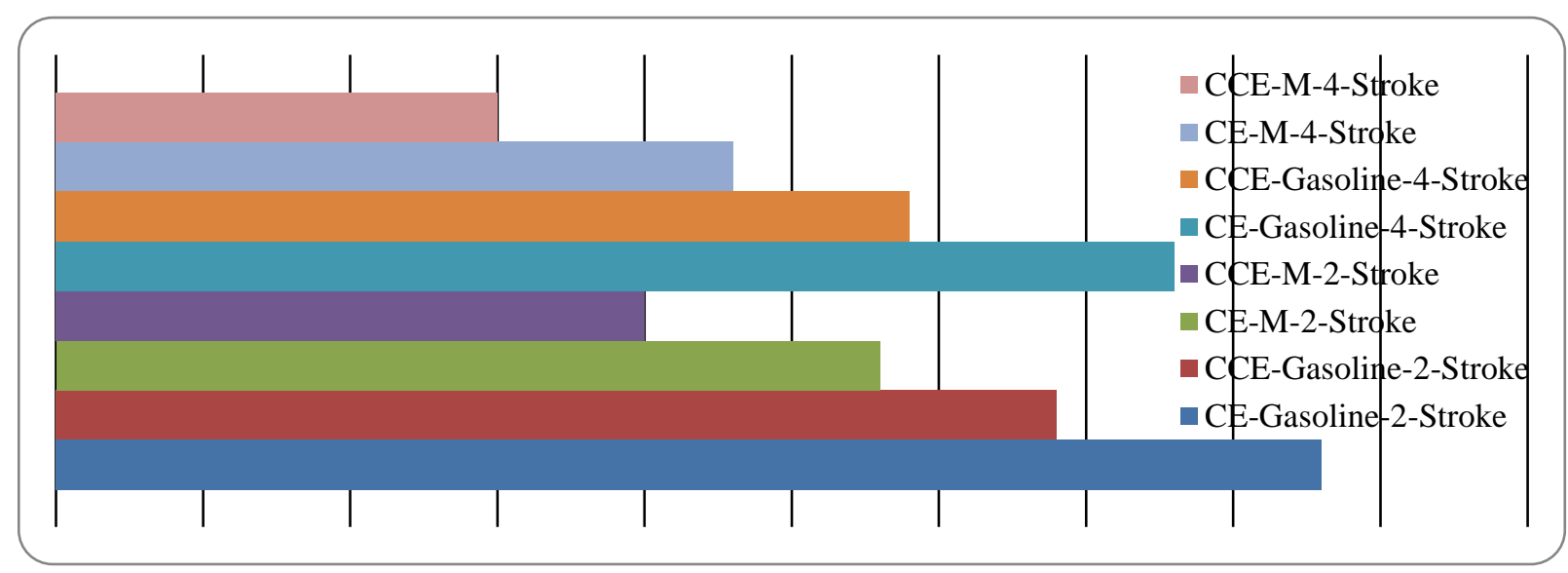

Figure 5 Bar charts showing the variation of $\mathrm{CO}$ emissions of at full load operation 
Figure. 6 presents bar charts showing the variation of UBHC emissions at full load for 2 stroke and 4 stroke SI engine with different test fuels and with different configurations of the engine. Figure. 6 indicates that UBHC emissions followed the same trend as $\mathrm{CO}$ emissions in CCE and CE with both test fuels, due to increase of flame speed with catalytic activity and reduction of quenching effect with $\mathrm{CCE}$.

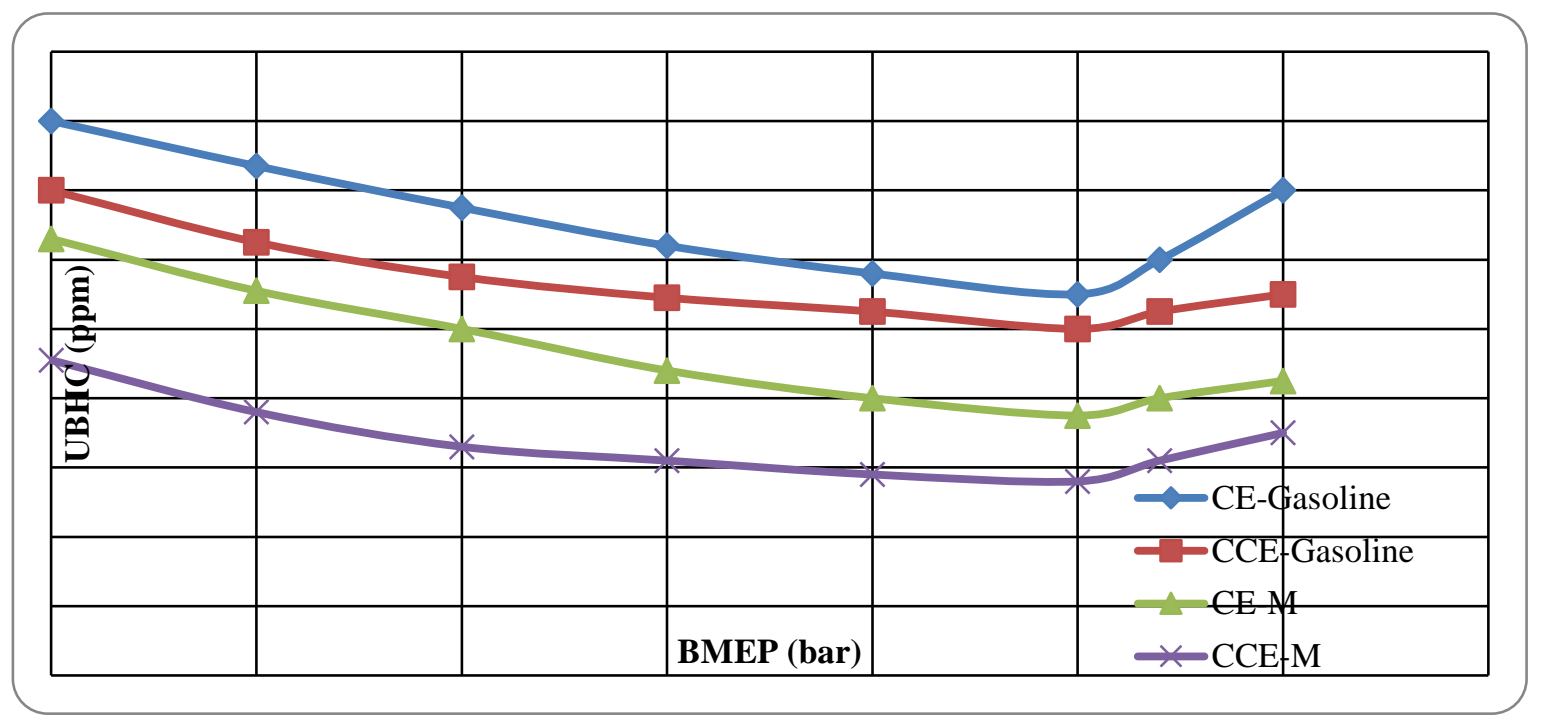

Figure 6 Variation of UBHC emissions with BMEP of 2-Stroke engine

Figure.7. presents bar charts showing the variation of UBHC emissions at full load for 2 stroke and 4 stroke SI engine with different test fuels and with different configurations of the engine.

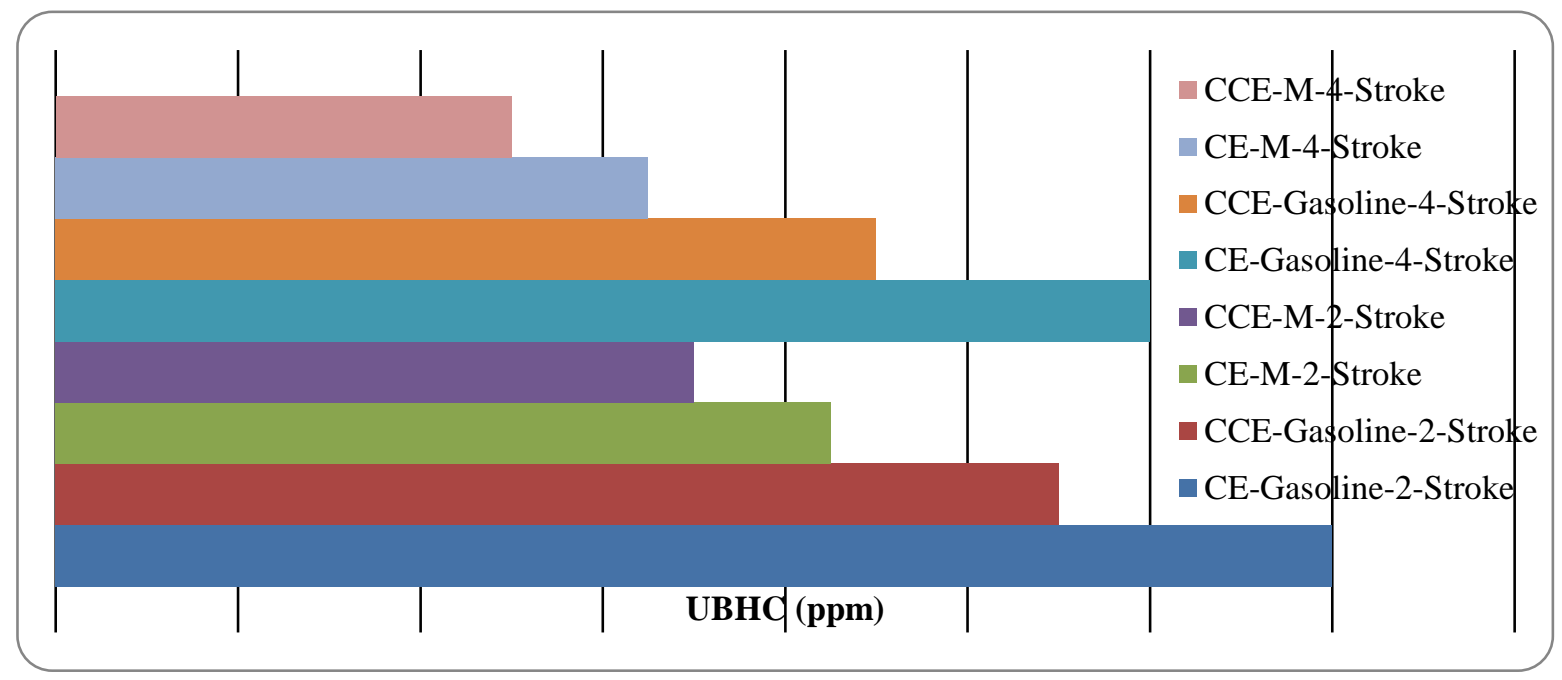

Figure 7 Bar charts showing the variation of UBHC emissions of at full load operation

From Figure.7, it is noticed that UBHC emissions at full load operation were observed to be less with 4-stroke engine in comparison with 2-stroke engine at peak load operation on both versions of the engine. This was due to increase of quenching effect with 2 -stroke engine leading to expel out of the fresh fuel without participating in combustion reactions causing higher amount of UBHC. 


\subsection{Catalytic Converter}

Table.1 presents data of exhaust emissions in 2 and 4-strokes engine. Catalytic converter reduced pollutants considerably with $\mathrm{CE}$ and $\mathrm{CCE}$ and air injection into catalytic converter further reduced pollutants. In presence of catalyst, pollutants get further oxidised to give less harmful emissions like $\mathrm{CO}_{2}$. Set- $\mathrm{A}=$ Without catalytic converter and without air injection, Set$\mathrm{B}=$ With catalytic converter and without air injection, Set- $\mathrm{C}=$ With catalytic converter and with air injection. From Table-1, it is observed that $\mathrm{CO}$ emissions decreased considerably with SetB operation, while Set-C further decreased emissions in both versions of the engine with test fuels. Efficient combustion with methanol blended gasoline coupled with catalytic activity decreased CO emissions in CCE. From same Table, it can be noticed that UBHC emissions decreased considerably with Set-B operation, while Set-C further decreased emissions in both versions of the engine with test fuels. Improved combustion with methanol blended gasoline along with turbulence with catalytic activity decreased deposits in CCE causing decrease of UBHC emissions. $\mathrm{CO}$ and UBHC emissions were observed to be higher with 2 stroke engine in comparison with 4 stroke engine with different versions of the engine with different test fuels at same compression ration and speed. From the Table, it can be noticed that formaldehyde emissions decreased considerably with Set-B operation, while Set-C further decreased emissions in both versions of the engine with test fuels. However, methanol blended gasoline increased aldehyde emissions considerably in comparison with pure gasoline operation. But CCE decreased aldehyde emissions in comparison with CE with both test fuels. This is due to improved combustion so that intermediate compounds will not be formed. 2-Stroke engine increased aldehyde emissions than 4 stroke engine as combustion reactions are incomplete with 2 stroke engine.

Table 1 Data of Exhaust Emissions in Four-stroke and Two-stroke SI engine with different test fuels at different operating conditions of catalytic converter

\begin{tabular}{|c|c|c|c|c|c|c|c|c|c|}
\hline \multirow{3}{*}{ Emissions } & \multirow[t]{3}{*}{ Set } & \multicolumn{4}{|c|}{ Pure Gasoline Operation } & \multicolumn{4}{|c|}{ Methanol Blended Gasoline } \\
\hline & & \multicolumn{2}{|c|}{$\mathrm{CE}$} & \multicolumn{2}{|c|}{ CCE } & \multicolumn{2}{|c|}{$\mathrm{CE}$} & \multicolumn{2}{|c|}{ CCE } \\
\hline & & $2 \mathrm{~S}$ & $4 \mathrm{~S}$ & $2 \mathrm{~S}$ & $4 \mathrm{~S}$ & $2 \mathrm{~S}$ & $4 \mathrm{~S}$ & $2 \mathrm{~S}$ & $4 \mathrm{~S}$ \\
\hline \multirow{3}{*}{$\mathrm{CO}(\%)$} & Set-A & 4.3 & 3.8 & 3.4 & 2.9 & 2.8 & 2.3 & 2.0 & 1.5 \\
\hline & Set-B & 2.58 & 2.1 & 2.04 & 1.8 & 1.7 & 1.1 & 1.3 & 0.8 \\
\hline & Set-C & 1.2 & 0.9 & 1.0 & 0.8 & 0.7 & 0.6 & 0.6 & 0.5 \\
\hline \multirow{3}{*}{ UBHC (ppm) } & Set-A & 700 & 500 & 550 & 375 & 425 & 350 & 350 & 228 \\
\hline & Set-B & 370 & 310 & 250 & 220 & 235 & 175 & 190 & 130 \\
\hline & Set-C & 160 & 120 & 130 & 110 & 100 & 90 & 80 & 70 \\
\hline \multirow{3}{*}{$\begin{array}{l}\text { Formaldehyde } \\
\text { (\% Concentration) }\end{array}$} & Set-A & 6.5 & 4.5 & 5.5 & 4.5 & 12 & 10 & 11 & 8 \\
\hline & Set-B & 3.5 & 2.5 & 1.5 & 1.2 & 4.0 & 3.5 & 3.8 & 2.9 \\
\hline & Set-C & 2.2 & 1.7 & 1.5 & 0.8 & 4.2 & 3.8 & 2.9 & 1.9 \\
\hline \multirow{3}{*}{$\begin{array}{l}\text { Acetaldehyde } \\
\text { (\% Concentration) }\end{array}$} & Set-A & 8.5 & 7.0 & 6.0 & 5.0 & 15 & 12 & 10 & 9.0 \\
\hline & Set-B & 5.5 & 4.0 & 4.5 & 3.0 & 9 & 7 & 8 & 6.0 \\
\hline & Set-C & 4.0 & 3.0 & 3.3 & 2.1 & 8 & 6 & 7 & 5 \\
\hline
\end{tabular}

\section{CONCLUSIONS}

In comparison with 2-stroke CCE engine with methanol blended gasoline operation, $\mathrm{CO}$ emissions decreased by $25 \%$ and UBHC emissions decreased by $29 \%$ with 4 stroke CCE with methanol blended gasoline operation. 
In comparison with 4-stroke CCE engine with methanol blended gasoline, $\mathrm{CO}$ emissions decreased by $53 \%$ and UBHC emissions decreased by $50 \%$ when compared with CE with pure gasoline operation. CCE improved combustion and decreased exhaust emissions effectively in comparison with $\mathrm{CE}$ with test fuels. Set-B operation of the catalytic converter decreased the pollutants by $40 \%$, while Set- C by $60 \%$.

\section{ACKNOWLEDGEMENTS}

Authors thank authorities of Chaitanya Bharathi Institute of Technology, Hyderabad for facilities provided. Financial assistance from Andhra Pradesh Council of Science and Technology (APCOST), Hyderabad, is greatly acknowledged

\section{REFERENCES}

[1] Sharma, B.K, Engineering Chemistry, edited by B.K. Sharma [Pragathi Prakashan (P) Ltd, Meerut], 2012, PP. 150-160.

[2] Fulekar, M. H. Chemical pollution - a threat to human life, Indian Journal of Environmental Technology, 1, 2010, pp.353-359.

[3] Usha Madhuri, T., Srinivas, T. and Ramakrishna, K. A study on automobile exhaust pollution with regard to carbon monoxide emissions, Nature, Environment and Pollution Technology, 2, pp.473-474.

[4] Environmental Pollution Analysis, edited by Khopkar, S.M. [New Age International (P) Ltd, Publishers, New Delhi], 2004, pp.180-190.

[5] Ghose, M. K., Paul, R. and Benerjee, S. K. Assessment of the impact of vehicle pollution on urban air quality, Journal of Environmental Science and Engineering, 46, 2004, pp.33-40.

[6] Murali Krishna, M.V.S. and Kishor, K. Control of pollutants from copper coated spark ignition engine with methanol blended gasoline. Indian Journal of Environmental Projection, 25(8), 2005, pp. 732-738.

[7] Engineering Chemistry, edited by Sharma, B.K. [Pragathi Prakashan (P) Ltd, Meerut], 2005, pp. 150-160.

[8] Nedunchezhian, N. and Dhandapani, S. Experimental investigation of cyclic variation of combustion parameters in a catalytically activated two-stroke SI engine combustion chamber. Engineering Today, 2, 2005, pp. 11-18.

[9] Murali Krishna, M.V.S., Kishor, K., Murthy, P.V.K., Gupta, A.V.S.S.K.S. and Narasimha Kumar, S. Performance evaluation of copper coated four stroke spark ignition engine with gasohol with catalytic converter. International Journal of Engineering Studies,2(4),2010, pp.465-473.

[10] Narasimha Kumar,S., Murali Krishna, M.V.S., Murthy, P.V.K., Seshagiri Rao, V.V.R. and Reddy, D.N. Performance of copper coated two stroke spark ignition engine with gasohol with catalytic converter. International Journal on Mechanical \& Automobile Engineering, 12(1), 2011, pp. 36-43

[11] Narasimha Kumar, S., Murali Krishna, M.V.S., Murthy, P.V.K., Reddy, D.N. and Kishor, K.Performance of copper coated two stroke spark ignition engine with gasohol with catalytic converter with different catalysts. International Journal of Applied Engineering Research, Dindigul, 2(1),2011, pp. 205-218 
[12] Murali Krishna, M.V.S., Kishor, K., Gupta, A.V.S.S.K.S., Murthy, P.V.K., and Narasimha Kumar, S. Performance of copper coated two stroke spark ignition engine with methanol blended gasoline with catalytic converter, International Journal of Sustainable and Renewable Energy,4(1),2012, pp. 013102.1-013102.9

[13] Narasimha Kumar, S., Murali Krishna, M.V.S., Krishna Murthy, P.V., Seshagiri Rao, V.V.R. and Reddy, D.N. Emissions from copper coated two-stroke spark ignition engine with gasohol with catalytic converter. International Journal of Mechanical Engineering, 3(2),2010, pp.163167.

[14] Narasimha Kumar, S., Kishor,K., Murali Krishna, M.V.S., and Murthy, P.V.K. Studies on exhaust emissions from copper coated gasohol run spark ignition engine with catalytic converter. International Scholarly Research Net Work (ISRN) in Mechanical Engineering (ME), Article 757019, 2011, pp. 1-6.

[15] Murali Krishna, M.V.S., Kishor, K., Murthy, P.V.K. and Gupta, A. V S. S. K .S. . Emissions from copper coated two-stroke spark ignition engine with methanol blended gasoline with catalytic converter. International Journal of Applied Engineering Research, 6(21),2011, pp. 2507-2516.

[16] Murali Krishna, M.V.S., Murthy, P.V.K., Narasimha Kumar, S. and Kishor,K. Control of exhaust emissions from copper coated gasohol run two spark ignition engine with catalytic converter. International Journal of Mechanical Engineering Research,1(1),2011, pp. 24-37.

[17] Al-Farayedhi, A. A., Al-Dawood, A. M. and Gandhidasan, P. Experimental investigation of spark ignition engine performance using oxygenated fuel. ASME Journal of Engineering for Gas Turbines and Power, 126, 2004.pp. 178-191.

[18] Abu-Zaid., Badran, O. and Yamin, J. Effect of methanol addition on the performance of spark ignition engines. Energy and Fuels, 18, 2004, pp. 312- 315,

[19] Nakata, K. The effect of ethanol fuel on a spark ignition engine, SAE Paper No.2006-01-3380. 2006.

[20] Pearson, R.J. Alcohol based fuels in high performance engines, SAE Paper No - 2007-01-0056, 2007.

[21] Bahattin Celik, M. Experimental determination of suitable ethanol-gasoline blend rate at high compression ratio for gasoline engine, Applied Thermal Engineering, 28, 2008, pp. 396-404.

[22] Rodrigo, C. Costa. and José, R. Sodré. Hydrous ethanol vs. gasoline-ethanol blend: engine performance and emissions, Fuel, 89, 2010, pp.287-293.

[23] Murali Krishna, M.V.S., and Kishor, K., Investigations on catalytic coated spark ignition engine with methanol blended gasoline with catalytic converter. Indian Journal (CSIR) of Scientific and Industrial Research, 67,2008, pp. 543-548.

[24] Murthy, P.V.K., Murali Krishna, M.V.S., Narasimha Kumar, S., Kishor, K. and Giridhar Reddy, P. Performance of copper coated two stroke spark ignition engine with alternate fuels with catalytic converter. International Journal of Engineering \& Techno-Science,„2(2),2011, pp. 145-149

[25] Murali Krishna, M.V.S., Kishor, K., Murthy, P.V.K. and Gupta, A.V.S.S.K.S. Control of exhaust emissions from copper coated two stroke spark ignition engine with methanol blended 
gasoline with catalytic converter. International Journal of Engineering and Innovative Technology,1(5), 2012, pp. 9-16.

[26] Murali Krishna, M.V.S., Kishor, K., Murthy, P.V.K., Gupta, A.V.S.S.K.S. and . Narasimha Kumar, S. Comparative studies on emissions from two stroke copper coated spark ignition engine with alcohols with catalytic converter. International Journal of Scientific \& Technology Research,1(2), 2012, pp.,85-90.

[27] Murali Krishna, M.V.S., Kishor, K., Murthy, P.V.K., Gupta, A.V.S.S.K.S. and Narasimha Kumar, S. Comparative studies on performance evaluation of a two stroke copper coated spark ignition engine with alcohols with catalytic converter. International Journal of Renewable and Sustainable Energy Reviews,16,2012, 6333-6339.

[28] Murthy, P.V.K., Narasimha Kumar, S., Murali Krishna, M.V.S., Seshagiri Rao, V.V.R. and Reddy, D.N. Aldehyde emissions from two-stroke and four-stroke spark ignition engines with methanol blended gasoline with catalytic converter. International Journal of Engineering Research and Technology,3(3),2010, pp. $793-802$.

[29] Murali Krishna, M.V.S., Narasimha Kumar, S. and Krishna Murthy, P.V. Control of aldehyde emissions from copper coated spark ignition engine fueled with alcohol blended gasoline. International Journal of Engineering Research and Applications,1(2), 2011, pp. 337-340

[30] Murthy, P.V.K., Narasimha Kumar, S., Kishor, K. and Murali Krishna, M.V.S. Aldehyde emissions from two-stroke and four-stroke spark ignition engines with catalytic converter running on gasohol. International Journal of Fuels and Lubricants, 50(2),2011, pp. 137-156 